\title{
Review of the Poorly Known Harvestman Subfamily Opilioninae (Arachnida: Opiniones: Phalangiidae) with Himalphalangium spinulatum from Korea
}

\author{
Soo-Hong Ban ${ }^{1}$, Tae-Seong Kwon ${ }^{2}$ and Byung-Woo Kim ${ }^{3, *}$ \\ 'Department of Environmental \& Ecological Engineering, Dongguk University, Seoul 100-715, Korea \\ ${ }^{2}$ Department of Forest Ecology, Korea Forest Research Institute, Seoul 133-712, Korea \\ ${ }^{3}$ National Park Research Institute, Jucheon-myeon, Namwon-si, Jeollabuk-do 590-811, Korea
}

\begin{abstract}
Himalphalangium spinulatum (Roewer, 1911) collected from Gijang-gun, Busan-city, Korea is redescribed with spination of leg, detailed illustrations including SEM photographs for the first time. Bidentolophus bidens (Simon, 1880) as a junior synonym of Opilio koreanus Charitonov, 1957 from North Korea is additionally reported in the Korean fauna. Also, a key to the species of Korean subfamily Opilioninae is provided.
\end{abstract}

Keywords: taxonomy, harvestman, Opilioninae, Himalphalangium spinulatum, Korea

\section{INTRODUCTION}

Harvestmen or daddy long-legs are members of the order Opiliones of the class Arachnida and is known to be rather poorly studied in Korea. This group constitutes the third largest order of the arachnids, with more than 5959 described species, 1489 genera and 45 families including four suborders (Pinto-da-Rocha and Giribet, 2007). Of these, Martens (1973) created the genus Himalphalangium to accommodate the type species, H. palpale (Roewer, 1956). Five species belonged to the genus and after Starega (2003) added $H$. spinulatum (Roewer, 1911) to the genus by morphological characters of penis. In this study we redescribe Himalphalangium spinulatum (Roewer, 1911) belonging to the subfamily Opilioninae of the family Phalangiidae. This species is only listed in Korean volcano-cave species, Opilio pentaspinulatus Suzuki, 1950 and is clearly distinguishable by palpal patella with teeth dorsally, palpal femur without large teeth and abdominal tergites without median spine. After original description of Opilio koreanus collected from Sinmuseong, Yanggang-do, North Korea in Russian by Charitonov (1957) this species is not recorded in Korean fauna. Recently, Strarega (2003) synonymized this species to Bidentolophus bidens (Simon, 1880) with variable color patterns.

Therefore, we confirmed two Korean harvestmen species under the subfamily Opilioninae and a key to species of these taxa is provided. Females and males were collected with

*To whom correspondence should be addressed

Tel: 82-2-2296-7158, Fax: 82-2-2220-1481

E-mail: bwkim00@hotmail.com pitfall traps (plastic cups, height $6.3 \mathrm{~cm}$, diameter $8 \mathrm{~cm}$ ) in shrubs in Gijang-gun, Busan-city, Korea. Specimens were preserved with $70 \%$ ethanol. Before dissection, the whole body was drawn and body length measurements made from whole specimens temporarily mounted in lactophenol. SEM photographs were also taken for more detailed analysis. Scale bars in figures are in millimeters. Specimens examined in this paper will be deposited in National Park Research Institute of Korea (NPRI). The spination of legs and terminology follow that of Pinto-da-Rocha and Giribet (2007) and $\operatorname{Kim}(2009)$.

\section{SYSTEMATIC ACCOUNTS}

Class Arachnida Cuvier, 1812

Order Opiliones Sundevall, 1833

Family Phalangiidae Latreille, 1802

Key to the species of Korean Phalangiid harvestmen

1. Cheliceral teeth without small regular teeth (diaphanous teeth) ….......................................... 2 (Eupnoi)

- Cheliceral teeth with diaphanous teeth $\cdots$...other suborders

2. Pedipalpal tarsus longer than tibia and claw smooth ….... 3 (Phalangiidae)

- Pedipalpal tarsus longer than tibia or claw toothed other families

3. Pedipalpal patella and tibia without distomesal apophyses and shaft of penis dorsoventrally flattened

4 (Opilionianae) 
- Pedipalpal patella and tibia with distomesal apophyses and shaft of penis generally rounded $\cdots \cdots \cdots \cdot$ other subfamilies

4. Cheliceral femur with numerous denticles, ventrally with

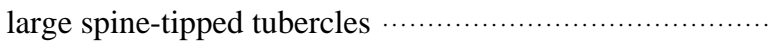

Bidentolophus biden (Simon, 1880)

- Cheliceral femur without denticles or large spine-tipped tubercles ‥ Himalphalangium spinulatus (Roewer, 1911)

${ }^{1}$ *Genus Himalphalangium Martens, 1973

${ }^{2}$ Himalphalangium spinulatum (Roewer, 1911) (Figs. 1-4)

Opilio spinulatus Roewer, 1911, p. 42; 1912, p.143, pl. 4, fig. 5.

Opilio pentaspinulatus Suzuki, 1950, p. 45. pl. 1, figs. 1-11; 1972, p. 454.

Opilio nigerrimus Schenkel, 1953, p. 94, fig. 43.

Himalphalangium spinulatum: Staręga, 2003, p. 93, figs. 6-

10.

Material examined. 6 ㄲ ㅈ, 35 우 우, Korea: Gijang-gun, Busan-city, 7 Jun. 2001 (T.S. Kwon) (NPRI).

Redescription. Male/Female (mm): Total body length 7.75/ 10.29; cephalothorax length 2.86/3.14, cephalothorax width 5.75/6.16, cephalothorax height 3.81/4.76; abdomen length 4.89/7.14, abdomen height 4.13/5.30, abdomen width 5.59/ 6.60 ; ocularium length $0.63 / 0.70$, ocularirum width 0.63 / 0.70 , oculararium height $0.35 / 0.35$; cheliceral length 2.42 / 2.39 , cheliceral width $1.09 / 1.26$; palp (femur $1.75 / 1.40$, patella $0.95 / 0.91$, tibia $1.16 / 1.05$, tarsus $2.02 / 2.10)$; 1 st leg $(4.49 /$ $3.51,1.80 / 1.68,3.52 / 2.70,4.14 / 3.87,4.49 / 6.48)$, 2nd leg (6.88/5.90, 1.88/2.03, 5.20/4.69, 5.12/5.78, 12.70/12.34), 3rd leg (4.96/4.10, 1.52/1.71, 3.59/3.24, 4.96/4.69, 7.34/7.15), 4th leg $(6.88 / 4.34,1.95 / 1.76,4.53 / 2.93,7.81 / 4.80,7.81 /$ 10.74); segmental number of 1 st distal tarsus (telotarsus or distitarsus) 26/25, segmental number of 2nd distal tarsus $44 / 45$, segmental number of 3rd distal tarsus 25/26, segmental number of 4th distal tarsus 29/29; penis length 4.74, penis width 4.38 , penis height 0.29 ; ovipositor length 5.23 , ovipositor width 0.80; genital operculum length 2.34/2.34, genital operculum width 1.95/1.95.

Male. Brown-colored harvestman covered with many granules and shorter than female. Cephalothorax (Fig. 1A-B), carapace with many large and small pointed teeth on the anterior part, and shallow grooves on the lateral; propeltidium with scattered teeth and mesopeltidium and metapeltidium armed with a transverse row of pointed minute teeth; trident present and suprachelicera absent; repugnatorial glands (Ozopores or scent glands) visible on the side and armed tubercles with 3-4 minute teeth. Eye (Figs. 1A-B, 5A), a pair of simply eyes placed on a low ocularium (ocular tubercle or eye mound) with five minute teeth vertically. Chelicerae (Fig. 1C), basal article with short setae on the dorsal part and ventrolateral and no denticle or large tubercle; distal article with short setae on the dorsal and apicolateral. Palp (Figs. 1D, 5F), throchanter armed with five teeth (no in female) and short setae; femur and tibia with blunt teeth and short setae; patella with small teeth dorsally; tarsus armed blunt teeth with numerous short setae and one hooked palpal claw on the distal. Mouthpart (Fig. 1H), labium shorter than female and a pointed lobe-shaped; coxapophyses (endites, maxillary lobes) of legs I and II with short seta sparsely and palpal coxapophysis without setae; coxapophyses swollen and sternum short placed on the lower of mouthpart.

Legs (Fig. 2D-G), legs long and slender with a single claw; coxae armed with two teeth apically armed and with short scattered setae; trochanter armed with five to ten teeth laterally; femur cylindrical in cross section, with minute teeth and no nodules; patella and tibia pentagonal, with rows of short teeth and short setae on the edges; tibia with two accessory spiracles, one near the proximal and one near the apical end, and two teeth and one spine on the apical; metatarsi with a pair of spines on the ventroapical; spination of leg metatarsi on the ventral, leg metatarsus I 0-2-6 $(1+1,2,2$ apical), II 0-0-2 apical, III 1-7 (3, 3, 1)-4 (2, 2, 2 apical), IV 0-2-4 (2, 2, 2 apical); tarsi with proximal metatarsi (undivided segment) and distal tarsi (tarsomere multisegmented) to be prehensile; segmental number of distal tarsi, leg I (26), II (55), III (26), IV (29); spine of distal tarsi on the ventral, leg I 1st segment to 8 th (absent)-9th to 10th (present)-11th (absent)-12th to 26th (present), leg II 1st segment to 26th (absent)-27th to 55th (present), leg III 1st segment to 8th (absent)-9th to 13th (present)-14th (absent)-15th to 17th (present)-18th (absent)19th to 27 th (present), leg IV 1st segment to 8th (absent)-9th to 29 th (present).

Abdomen (Fig 1A-B), abdominal tergite fused five tergites with a longitudinal row of largely pointed spines and tracheal spiracles located on the abdominal somite II posterior to leg IV coxae. Penis (Figs. 1E-G, 2A-C, 5C-D), male eversible organ (penis or spermatopositor) with glans about the shape of cobra head not flattened ventrally, and slender shaft characterized with characteristic subapical-ventral keel, a pore on the distal part and four small spines on the lateral.

Female. Coloration and form as in male except for the following characters (Figs. 3-4); armaments weaker than male, median spines on abdominal tergites less, pedipalp smooth and leg patella and femur with a few fine teeth. Spination of leg metatarsi on the ventral, leg metatarsus I 0-5 (3,2)-4 (2,2 apical), II 0-0-6 (2,2,2 apical), III 0-6 (4,2)-4 (2,2), IV 0-2-

\footnotetext{
${ }^{1 *}$ 히말통거미속 (신칭), ${ }^{2 *}$ 뿔히말통거미 (개칭)
} 

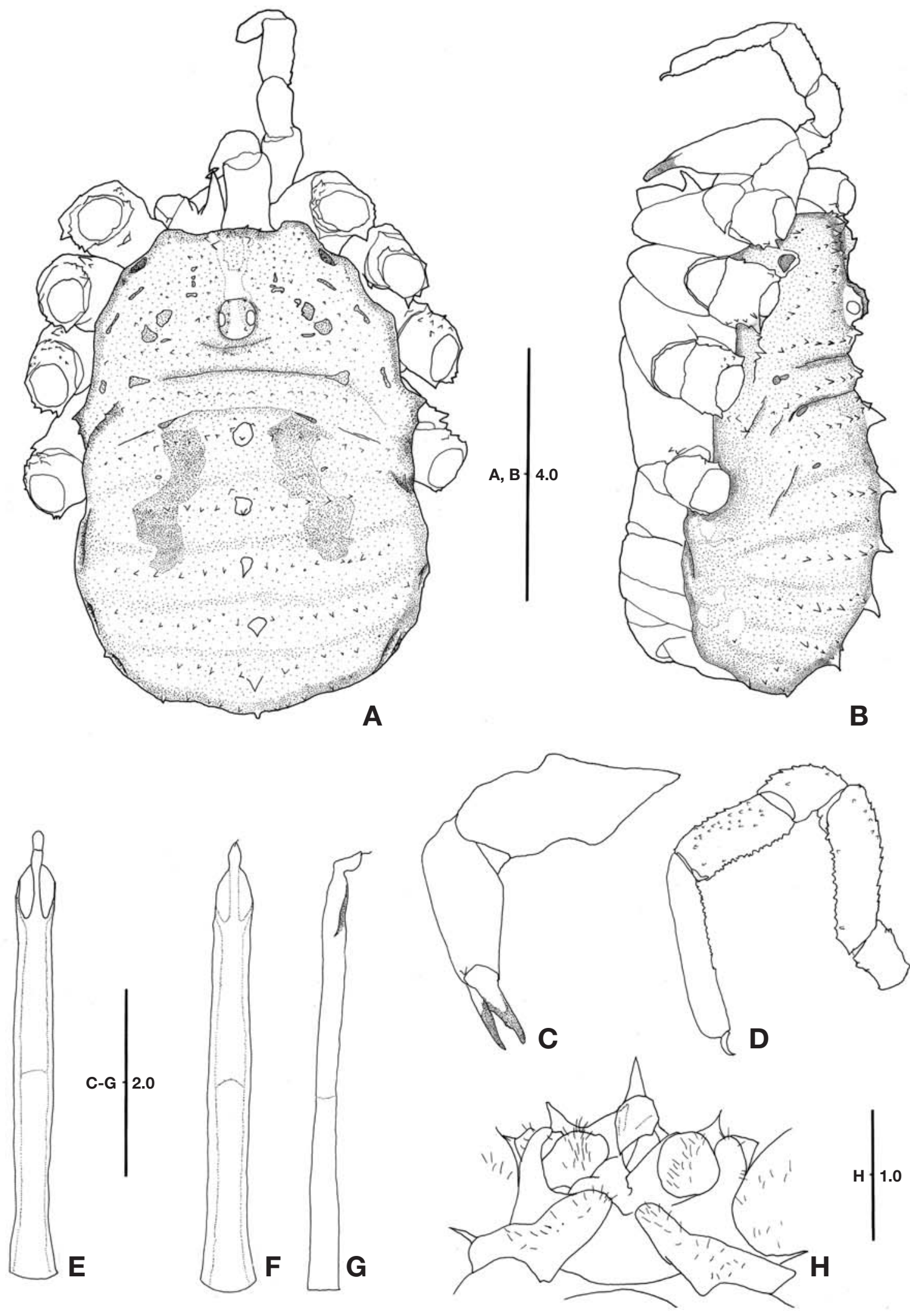

Fig. 1. Himalphalangium spinulatum (Roewer, 1911) in Korea, male: A, habitus, dorsal view; B, habitus, lateral view; C, chelicera (left), lateral view; D, palp (left), lateral view; E-G, penis, dorsal (E), ventral (F) and lateral view (G); $H$, mouth part, ventral view. 


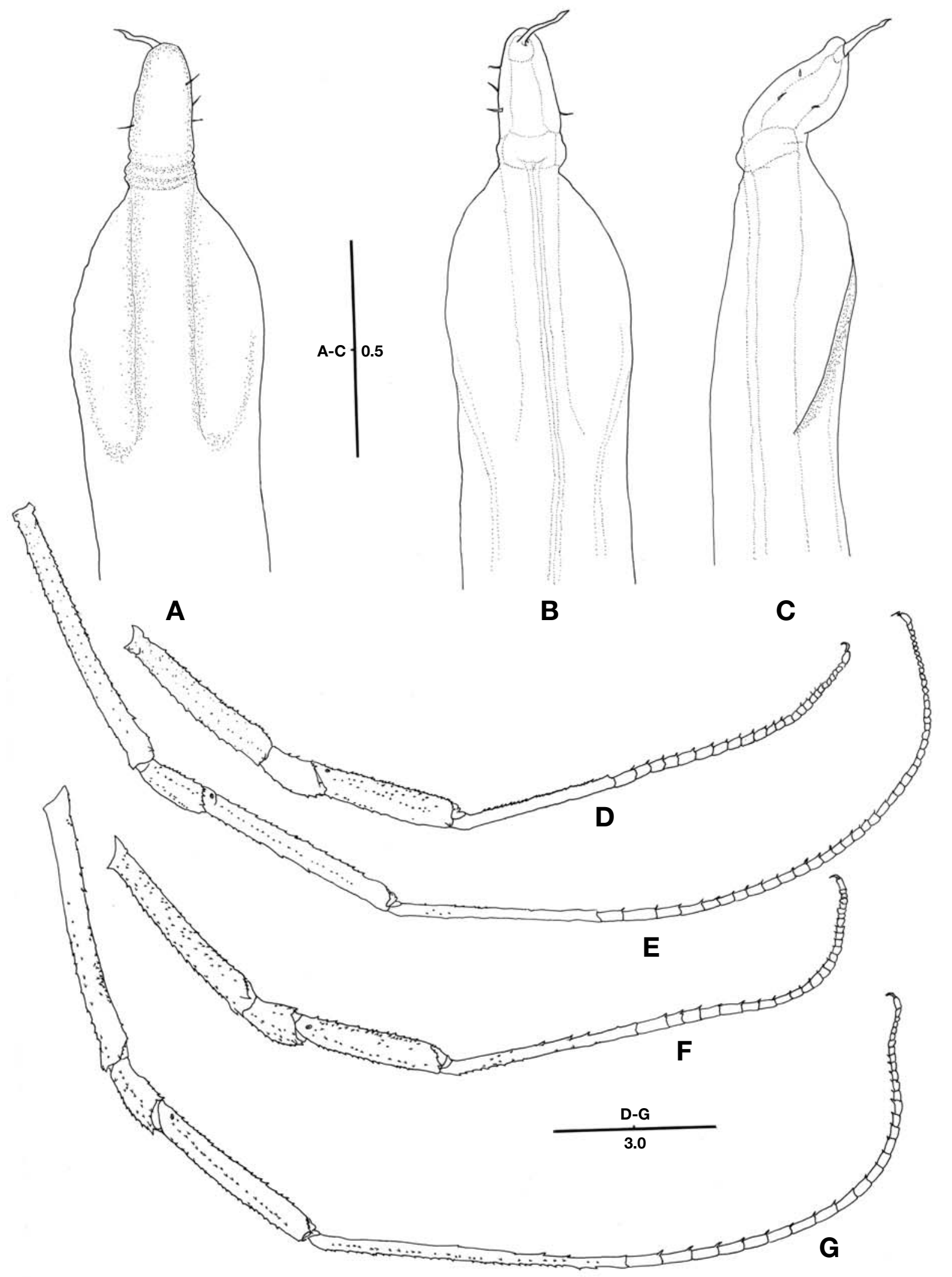

Fig. 2. Himalphalangium spinulatum (Roewer, 1911) in Korea, male: $A-C$, penis, dorsal (A), ventral (B) and lateral view (C); D-G, leg (right), retrolateral view, leg I (D), II (E), III (F) and IV (G). 

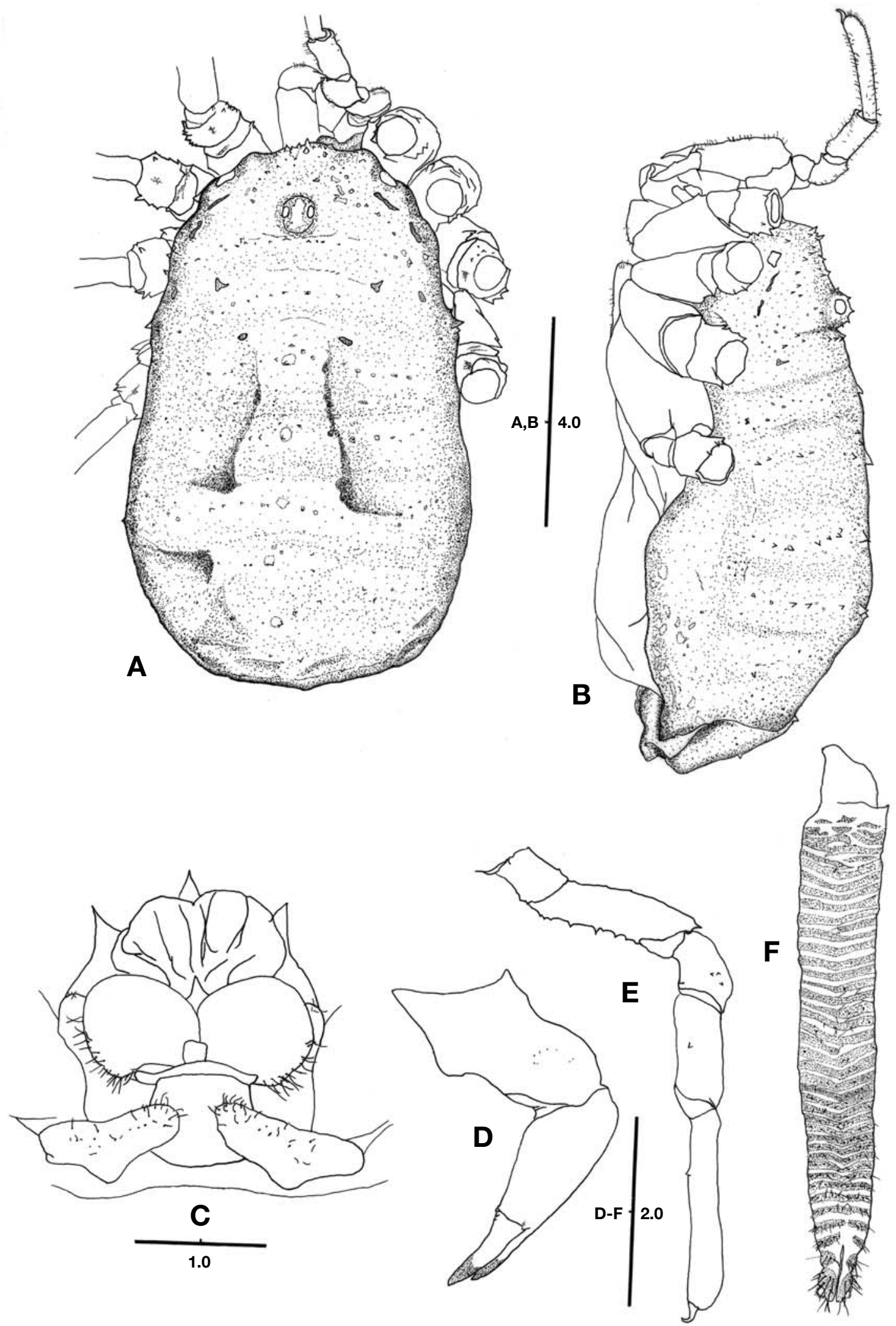

Fig. 3. Himalphalangium spinulatum (Roewer, 1911) in Korea, female: $A$, habitus, dorsal view; $B$, habitus, lateral view; , mouth part, ventral view; D, chelicera (right), lateral view; E, palp (right), lateral view; F, ovipositor, dorsal view. 

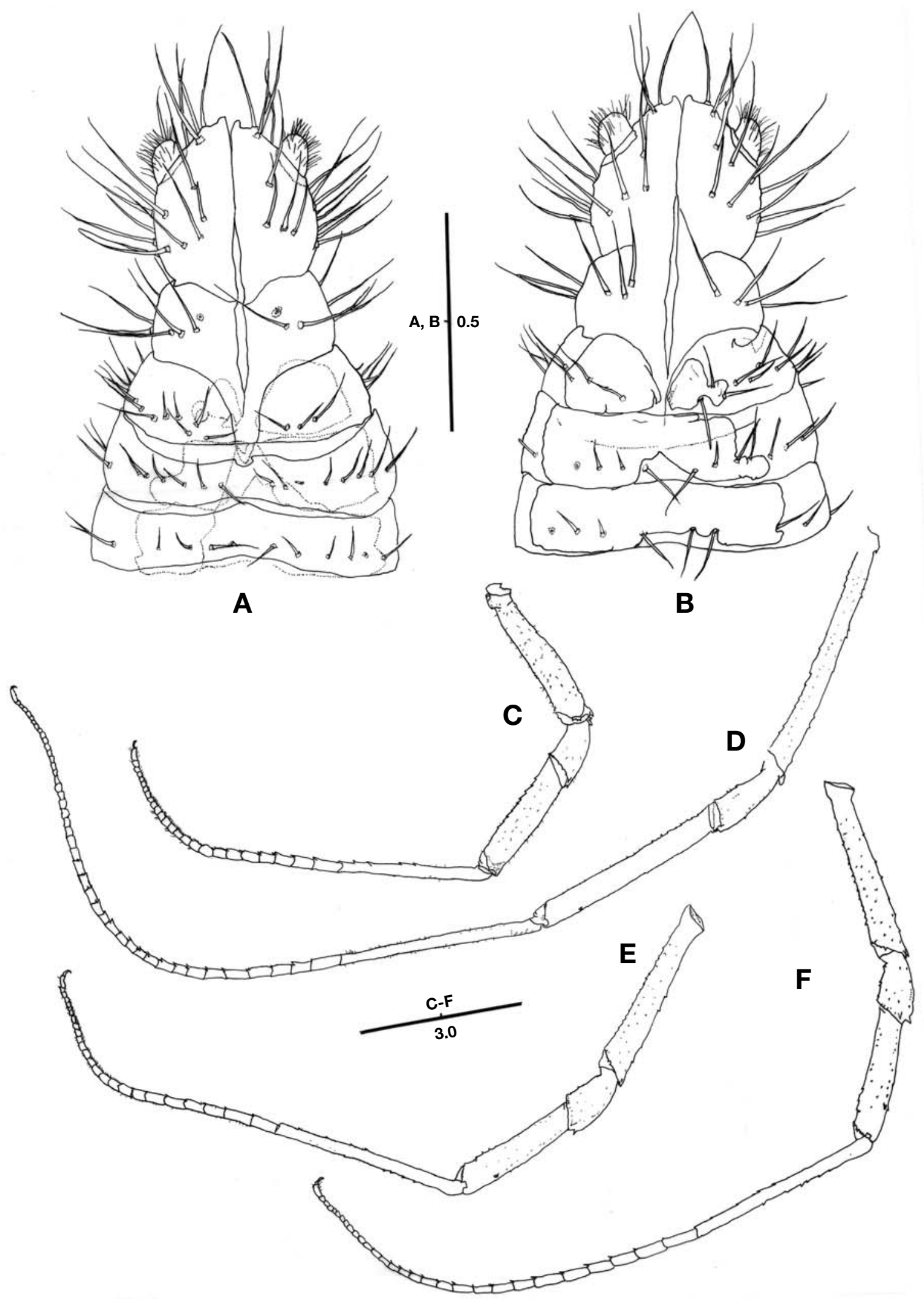

Fig. 4. Himalphalangium spinulatum (Roewer, 1911) in Korea, female: $A-B$, ovipositor, dorsal (A) and ventral (B); C-F, leg (left), prolateral view, leg I (C), II (D), III (E) and IV (F). 

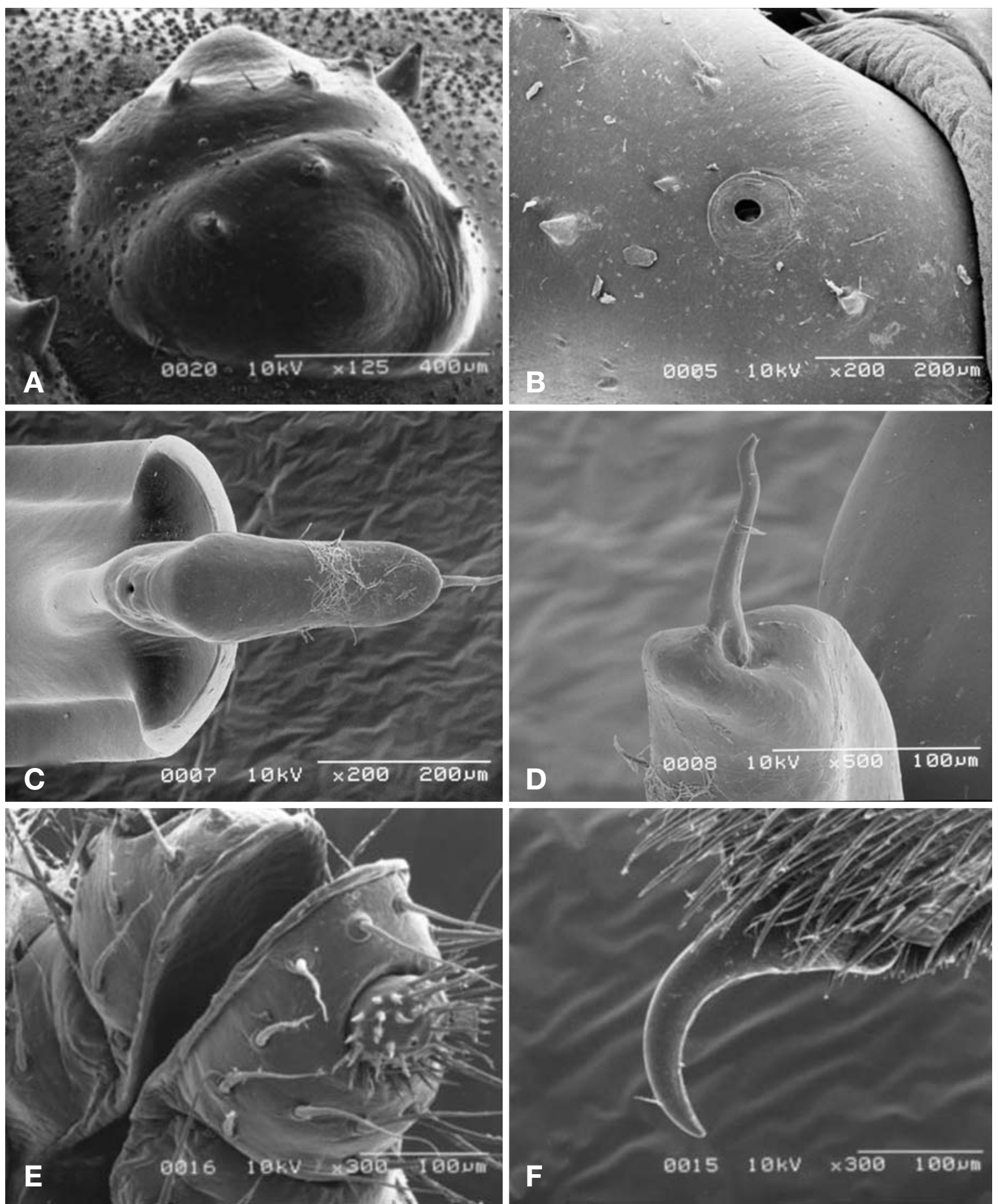

Fig. 5. SEM photographs of Himalphalangium spinulatum (Roewer, 1911) in Korea: A, ocularium, male; B, tracheal spiracle on 2nd leg tibia, male; C-D, penis, male, anterior (C) and apical part (D); E, ovipositor, distal part, female; F, palpal claw, left, male.

2a.0-2-6 (1+1, 2, 2 apical). Ovipositor (Figs. 3F, 4A-B, 5E) second furcal joint with a slit sensillum per side. Each segment strongly stained with dark brown pigments. Seminal receptacles located within 1 st to 3 rd ovipositor rings, with two elongated atria.

Distribution. China (Southern Manchuria), Japan (Kumamoto Prefecture, Fukuoka Prefecture, Oita Prefecture), Korea (Is. Jejudo, Busan-city), Russia (Khabarovsk). 
${ }^{1 * G e n u s ~ B i d e n t o l o p h u s ~ R o e w e r, ~} 1912$

${ }^{2} *$ Bidentolophus bidens (Simon, 1880)

Accantholophus bidens Simon, 1880, p. 126.

Bidentolophus bidens: Roewer, 1912, p. 82; 1923, p. 744, fig. 923; Tsurusaki \& Song, 1998, p. 526, fig. 47.

Euphalangium transbaicalicum: Redikorzev, 1936, p. 33; Silhavy, 1972, p. 102, figs. 1-8; Gritsenko, 1979a, p. 131, fig. 17; Gritsenko, 1979b, p. 38, fig. 34.

Egaenus bidens: Strarega, 1978, p. 221.

Opilio multidentatus: Suzuki, 1956, p. 91, figs. 1-10.

Opilio hexaspinulatus Saito, 1936, p. 9.

Opilio koreanus Charitonov, 1957, p. 1417, fig. 1.

Opilio peipingensis Wang, 1941, p. 113.

Opilio tchangi Wang, 1941, p. 110.

Homolophus pallens (Kulczynski, 1901) in Tsurusaki et al. (2000).

Remarks. Coloration mostly sandy-yellow with dark brown patterns and a biogeographic difference between the eastern and western populations in China: coxae with numerous denticles, value of body length index relatively higher, penis a little longer and not broadened at the base in the eastern (Starega, 2003).

Distribution. North Korea (Sinmuseong, Yanggang-do), China, Russia (Siberia).

\section{ACKNOWLEDGEMENTS}

The authors wish to express their sincere thanks to Mr. J. Namkung, Seoul and Dr. N. Tsurusaki of the Tottori University, Japan for providing many valuable specimens and several important papers. This study was partially supported by Korea Forest Research Institute (KFRI). Some results were obtained as results of KFRI preject 'Development of Forest Eco-Map of Korea'.

\section{REFERENCES}

Charitonov, D.E., 1957. New Opiliones from Korea. Zool. Zhurnal., 36: 1417-1420 (in Russian).

Gritsenko, N.I., 1979a. The harvestmen (Opiliones) from the Asian part of the USSR. In: Fauna I ecologiya paukoobraznykh (Ed., Yu.S. Balashov). Trudy Zool. Inst. AN SSR, 85: 28-38 (in Russian).

Gritsenko, N.I., 1979b. Materials on the harvestmen fauna(Opiliones) of the Martime Province. In: Nazemnye chlenistonogie Dal'nego Vostoka (Ed., P.A. Ler). pp. 124-132. AN
SSR., Vladivostok (in Russian).

Kim, B.W., 2009. Two new species of the genus Alloclubionoides (Araneae: Amaurobiidae) in Korea. J. Nat. Hist., 43: 45-48.

Kulczynski, W., 1901. Arachnoidea. In: Zoologische Ergebnisse der dritten asiatischen Forschungsreise des Grafen Eugen Zichy (Ed., G. Horvath). 2, pp. 311-369. Budapest.

Martens, J., 1973. Opiliones aus dem Nepal-Himalaya. II. Phalangiidae und Sclerosomatidae (Arachnida). Senckenbergiana Biol., 54: 181-217.

Pinto-da-Rocha, R. and G. Giribet, 2007. Taxonomy. In: Harvestmen: the biology of the Opiliones (Eds., R. Pinto-daRocha, G. Machado and G. Giribet). pp. 88-246. Harvard Univ. Press, Cambridge and London.

Redikorzev, V.V., 1936. Materials to the fauna of Opiliones of the USSR. Trav. Inst. Zool. Acad. Sci. URSS., 3: 33-37 (in Russian with German summary).

Roewer, C.F., 1911. Über der Genera der Subfamilie der Phalangiini der Opiliones Palpatores nebst Beschreibung einiger neuer Gattungen und Arten. Archi. Naturg., 77(Suppl. 2): 1-106.

Roewer, C.F., 1912. Revision der Opiliones Palpatores. II. Teil. Familie der Phalangiidae (Subfamilien: Sclerosomatini, Oligolophini, Phalangini). Arch. naturw. Ver., Hamburg, 20: 1-295.

Roewer, C.F., 1923. Die Weberkenchte der Erde. Systematische Bearbeitung der bisher bekannten Opilienes. Gustav Fischer, Jena, pp. 1-1116.

Roewer, C.F., 1956. Über Phalangiinae (Phalangiinae, Opiliones, Palpatores). (Weitere Weberknechte XIX). Senkenbergiana boil., 37: 247-318.

Saito, S., 1936. Arachnida of Jehol - Orders: Scorpiones, Araneina, Opiliones \& Acarina. Order Opilines. Rep. First Sci. Exped. Manchoukuo, Sec. V, Div. I, Part IV, Art. 12, pp. 112.

Schenkel, E., 1953. Chinesische Arachnoidea aus dem Museum Hoangho-Peiho in Tientsin. Bol. Mus. Nac., N. S., Zoologia, 119: 1-108.

Silhavy, V., 1972. Asiatische Arten der Gattung Euphalngium Roewer (Arachnida: Opiliones: Phalangiidae). Senckenbergiana Biol., 53(1/2): 101-108.

Simon, E., 1880. Etudes arachnologiques. 11e Memoire. XVII. Arachnides recueilles aux environs de Pekin par M. V. Collin de Plancy. Ann. Soc. ent. Fr., 10(5): 97-128.

Strarega, W., 1978. Katalog der Weberknechte (Opiliones) der Sowjet Union. Fragmenta Faun., 23(10): 197-241.

Starega, W., 2003. On the identity and synonymies of some Asiatic Opilioninae (Opiliones: Phalangiidae). Acta Arachnol., 52(2): 91-102.

Suzuki, S., 1950. Studies on the Japapanese Harvesters. III. Description of a New Species, Opilio pentaspinulatus from Japan. J. Sci. Hiroshima Univ., 11(5): 45-48.

Suzuki, S., 1956. A new phalangid, Opilio multidentatus n. sp.

$1 *$ 두가시통거미속(신칭), ${ }^{2 *}$ 두가시통거미 (신칭) 
from southern Manchuria. J. Sci. Hiroshima Univ., 16: 91-95.

Tsurusaki, N., A.N. Tchemerus and D.V. Logunov, 2000. Two New Species of Opiliones from Southern Siberia and Mongolia, with an Establishment of a New Genus and Redefinition of the Genus Homolophus (Arachnida: Opiliones: Phalangiidae). Acta Arachnologica, 49(1): 73-86.

Tsurusaki, N. and D.X. Song, 1998. Order Opiliones. In: Picto- rial Keys to Soil Animals (Ed., W.Y. Yin). pp. 155-162, 523527. Science Press, Bejing (in Chinese).

Wang, F., 1941. Chinensische Spinnentiere. I. Opiliones. Zool. Anz., 135: 97-115.
Received January 22, 2010 Accepted March 11, 2010 